\title{
RETHINKING COPYRIGHT: PROPERTY THROUGH THE LENSES OF UNJUST ENRICHMENT AND UNFAIR COMPETITION
}

\author{
SHYAMKRISHNA BALGANESH ${ }^{\dagger}$
}

In response to Sara K. Stadler, Copyright as Trade Regulation, 155 U. PA. L. REV. 899 (2007).

For some time now, scholars have come to recognize the existence of numerous structural infirmities deeply embedded within the modern copyright system. ${ }^{1}$ Most of these infirmities have been attributed to internal tensions within copyright law and policy, including the competing philosophies of access and control, use and exclusion, and rights and exceptions. Professor Stadler's insightful article documents these tensions and proposes a new way of mediating them. ${ }^{2}$ She argues that copyright law is best understood as instantiating a restriction on unfair competition and, consequently, that it should do little more than protect creators of original works from "competitive harm" in a previously identified ("relevant") market." She goes on to propose that this principle be applied exogenously in determining the structure of copyright, and that the copyright grant be reformulated to consist of no more than an exclusive right to distribute works publicly. ${ }^{4}$

While I share Professor Stadler's belief that copyright law ought to be visualized as a doctrine of unfair competition, my concern lies with her solution, which I believe does not commit copyright law sufficiently to the goal she identifies for it. This Response argues for an alternative conception of unfair competition within copyright doc-

\footnotetext{
${ }^{\dagger}$ Bigelow Teaching Fellow \& Lecturer in Law, University of Chicago Law School. B.C.L., M.Phil., University of Oxford; J.D., Yale Law School. Thanks to Daniel Abebe, Irina Manta, James Grimmelmann, David Nimmer, Randy Picker, Sara Stadler, and Lior Strahilevitz for comments and discussions. The author can be reached at balganesh@uchicago.edu.

${ }^{1}$ See generally LaWrence Lessig, The Future of Ideas: The Fate of THE COMMONS IN A CONNECTED WORLD (2001); JESSICA LITMAN, DIGITAL COPYRIGHT (2001).

${ }^{2}$ Sara K. Stadler, Copyright as Trade Regulation, 155 U. PA. L. REV. 899 (2007).

${ }^{3}$ Id. at 933.

${ }^{4}$ See id. at 937-42 (contrasting public distribution rights with the more expansive notion of exclusive reproduction rights).
} 
trine: one that is premised on a restitutionary ideal and focuses on identifying unfair competition endogenously and contextually. If unfair competition is really what copyright is all about, then its principles ought to influence copyright law at every stage and not just in its ex ante structuring, as Professor Stadler suggests. Part I sets out the salient features of Professor Stadler's proposal—characterized by its use of unfair competition to structure copyright's exclusive rights framework. Part II contrasts this with a functional approach to unfair competition within copyright law. Part III then concludes by illustrating how the functional variant might work outside the confines of the reproduction right.

\section{THE STRUCTURAL MODEL}

Drawing an analogy to the "antitrust injury rule" that courts routinely apply in antitrust cases, Professor Stadler argues that copyright law ought to be similarly limited to an identifiable purpose, which she describes as protecting creators of original works from competitive harm in a relevant market. ${ }^{5}$ Interestingly though, she then parts company with antitrust law by concluding that the task of defining "relevant markets in copyrighted works" is best left to Congress and "not the courts." To Professor Stadler, the law should calibrate copyright's grant of exclusive rights to the primary market in which the owner ordinarily commercializes the work-and no more. ${ }^{7}$ Consequently, for printed works-"works that c[an] be replicated without diminishing their market value among intended users making intended uses" this entails limiting the grant to no more than an exclusive right to distribute the work publicly. ${ }^{9}$ Two prominent features characterize her model: 1) its reliance on Congress to identify the harms that copyright owners are entitled to be protected against; and 2) the de-

\footnotetext{
${ }^{5}$ See id. at 933-34 (noting the similarity between the antitrust injury rule and the general law of unfair competition). For more on the antitrust injury rule, see Roger D. Blair \& Jeffrey L. Harrison, Rethinking Antitrust Injury, 42 VAND. L. REV. 1539 (1989). See also Diane P. Wood, "Unfair" Trade Injury: A Competition-Based Approach, 41 STAN. L. REV. 1153, 1172-74 (1989) (advocating the extension of the antitrust injury rule into trade law more generally).

${ }^{6}$ Stadler, supra note 2, at 936 (internal quotation marks omitted).

${ }^{7}$ See supra note 4 and accompanying text.

${ }^{8}$ Sara K. Stadler, Forging a Truly Utilitarian Copyright, 91 IowA L. REv. 609, 634 (2006).

${ }^{9}$ Stadler, supra note 2 , at 937.
} 
lineation of harm, market and the scope of the owner's grant a priori through legislation.

It is not readily apparent why Professor Stadler prefers Congress to the courts, given that in recent times some of the most far-reaching limits on property rights within the context of both antitrust and copyright law have come from the courts rather than Congress. ${ }^{10}$ It may well be that she has little faith in the judicial branch's willingness to introduce radical changes; yet, her model does not altogether obviate the need for a shift in the way courts think of copyright and its goals. Professor Stadler's model still looks to courts to preempt attempts to circumvent copyright's statutory limits, to develop the doctrine of copyright misuse, and most importantly, to balance users' privileges against owners' exclusive (and exclusionary) rights; ${ }^{11}$ however, it does little to instantiate the goals of unfair competition into these myriad doctrines. Unless judges, on their own initiative, were to give effect to the goals of copyright that Professor Stadler posits, it is likely that her model would produce problems similar to the ones she identifies in the current system, almost all of which are the products of judicial interpretation.

Perhaps more importantly, Professor Stadler's model assumes that competitive harm and relevant markets, once identified, will remain constant for a given category of works. By eliminating altogether the reproduction right in relation to printed works, Professor Stadler's approach disregards the possibility that a market for a work may exist outside of its actual public distribution. For instance, a copyrighted work that is commercialized within the context of a business model (e.g., diagnostic software ${ }^{12}$ ) may be copied by a competitor in the

${ }^{10}$ In the context of copyright law, see Feist Publ'ns, Inc. v. Rural Tel. Serv. Co., 499 U.S. 340, 364 (1991) (finding the originality requirement to be mandatory before a work can be granted protection); Sony Corp. of Am. v. Universal City Studios, Inc., 464 U.S. 417, 442 (1984) (propounding the substantial noninfringing use defense to secondary liability); Fortnightly Corp. v. United Artists Television, Inc., 392 U.S. 390, 400-02 (1968) (disallowing copyright control over cable retransmissions). The judicial innovation known as the "essential facilities doctrine" in the antitrust context is similarly used to limit an owner's right to exclude. See Otter Tail Power Co. v. United States, 410 U.S. 366, 377 (1973) (ruling that an electric power company with a monopoly in an area had violated antitrust laws by refusing to deal with competitors that were dependent on it); United States v. Terminal R.R. Ass'n of St. Louis, 224 U.S. 383, 409 (1912) (finding entities that had combined to restrict all rail access to a river crossing to be in violation of antitrust laws).

${ }^{11}$ Stadler, supra note 2, at 949-58.

12 See MAI Sys. Corp. v. Peak Computer, Inc., 991 F.2d 511, 518-19 (9th Cir. 1993) (finding that the copying of software into RAM does constitute the creation of a copy under the Copyright Act, and that its use thereafter for business purposes is a copy- 
same field of operation, without actual public distribution. Freeriding of this nature is certainly a competitive harm, if the market were defined as one for services centered around the work.

Professor Stadler's structural model certainly solves the problems that she identifies in relation to unauthorized reproductions. While Professor Stadler acknowledges that her model is restricted to the narrow case of reproduction and distribution rights, ${ }^{13}$ it is clear that analogous recalibration will be needed to eliminate the problems that exist with copyright's other exclusive rights. If unfair competition as a principle entails no more than statutorily withholding one or more of a creator's rights under copyright law, or depending on a categorization of creative works that is external to copyright, it suffers from an obvious lack of flexibility-one that stands in stark contrast to antitrust law, where contextual doctrinal development has proven to be very successful.

\section{A FunCtional Alternative}

It remains possible, however, to conceive of unfair competition in terms of what common law scholars identify as the principle of "unjust enrichment." ${ }^{\prime 4}$ Deriving from the law of restitution, the principle of unjust enrichment simply provides that "[a] person who is unjustly enriched at the expense of another is liable in restitution to the other." 15

Standing by itself, the principle provides little direction, except to emphasize a norm of corrective justice. ${ }^{16}$ Yet, when applied to the context of one competitor's use of an intangible created by another, it gives rise to a workable ideal, which courts and scholars occasionally refer to as the doctrine of misappropriation or the prohibition on "reap [ing] where [one] has not sown."

right infringement). Leaving aside the issue of ephemeral copying, the plaintiff's business model relied heavily on its diagnostic software. See id. at 514-15.

${ }^{13}$ See Stadler, supra note 2, at 909 (leaving aside the rights of adaptation, display, and performance).

${ }^{14}$ See generally PETER Birks, UnJUST ENRICHMENT 3 (2003).

${ }^{15}$ Restatement (THIRD) OF RESTITUTION \& UnJust ENRICHMENT $\$ 1$ (Discussion Draft 2000); see also RESTATEMENT OF RESTITUTION § 1 (1937).

${ }^{16}$ See Jules L. Coleman, Intellectual Property and Corrective Justice, 78 VA. L. REV. 283, 284 (1992) (explaining that the principle of unjust enrichment only delineates the duty to relinquish wrongfully secured gains, not to whom those gains should ultimately be ascribed).

${ }^{17}$ Rudolf Callmann, He Who Reaps Where He Has Not Sown: Unjust Enrichment in the Law of Unfair Competition, 55 HARV. L. REV. 595, 612 (1942) (internal quotation marks 
While the Supreme Court is credited with being the first to link unfair competition to the principle of unjust enrichment in its infamous decision in International News Service v. Associated Press, ${ }^{18}$ the model has since been developed rather extensively by scholars. However, most of this has happened in the context of common law intellectual property and almost never within the confines of traditional copyright, where it is likely to be equally (if not more) effective. ${ }^{19}$

In a somewhat different context, Professor Wendy Gordon advocates the idea that liability for copying be premised on the existence of a "competitive nexus" between the plaintiff and the defendant, with the burden being placed on the plaintiff to establish that it is or shortly will be serving the market in which the defendant is operating. ${ }^{20}$ Using this nexus, she argues, satisfies unjust enrichment's requirement of detriment-i.e., that the defendant's profit be at the expense of the plaintiff. ${ }^{21}$

What might copyright law come to look like, if a similar nexus requirement were introduced to limit liability? Since copyright is about generating incentives for creation, we might want to connect this nexus requirement to copyright's instrumental purpose through a test of foreseeability. ${ }^{22}$ Given that liability for infringement is premised on a showing of copying, such a test would place the burden on the plain-

omitted). But see Richard A. Posner, Misappropriation: A Dirge, 40 Hous. L. REv. 621, 621 (2003) (arguing that misappropriation should be abandoned as a unifying principle of intellectual property law).

18248 U.S. 215, 240-42 (1918) (regarding news gathered by the plaintiff as property, unwillingly abandoned, and misappropriated by a competing news service).

${ }^{19}$ See, e.g., Leo J. Raskind, The Misappropriation Doctrine as a Competitive Norm of Intellectual Property Law, 75 MiNN. L. REv. 875, 906 (1991) (arguing that the common law doctrine of misappropriation be given analytical content by limiting it to "competitive markets").

${ }^{20}$ Wendy J. Gordon, On Owning Information: Intellectual Property and the Restitutionary Impulse, 78 VA. L. REV. 149, 221-22, 238-48 (1992).

${ }^{21} I d$. at 239 \& n.338.

${ }^{22}$ I bracket, for the moment, the question of why a test of foreseeability is indeed a meaningful basis on which to allocate the option value associated with a protected work. In brief, my reason derives from copyright law's theory of incentives and the idea of bounded rationality. As an instantiation of the principle of bounded rationality, foreseeability postulates that events and occurrences of low probability are incapable of providing individuals with incentives to act. See Mark F. Grady, Proximate Cause and the Law of Negligence, 69 IOWA L. REv. 363, 388-89 (1984) (understanding reasonable foresight as "an amount of information that would imply both a recognition and an estimation of expected harm"). If copyright is indeed about providing authors with an incentive to generate creative expression, then uses of a work (i.e., copying) that were unforeseeable to the creator when the work was created are unlikely to have formed any part of copyright's ex ante incentive and should therefore fall outside the creator's entitlement of exclusivity. 
tiff to show that the defendant's copying was in a market and of a form reasonably foreseeable when the work was created. This "foreseeable copying" test, even though based on the plaintiff's intent, would remain an objective determination temporally limited to the point of creation of the work. In market terms, it would thus ask, "Is the defendant's allegedly infringing use occurring in a market that the creator could have reasonably foreseen when he created the work?" ${ }^{23}$ This inquiry would ensure that a copyright owner is not able to define the market for the work ex post. Neither would an owner be able to influence a court's determination by hastily developing a new market. ${ }^{24}$ All the same, relegating this determination to courts (and not Congress) allows creators to innovatively develop business models around their works.

If a competitive nexus requirement were introduced as a principle of standing, operating in the same way as the antitrust injury rule does, it would serve to solve all of the problems that Professor Stadler identifies with the current regime. ${ }^{25}$ It would eliminate liability for private, noncommercial copying altogether since it would not entail any actual competition between the parties. It would also have the result of decreasing defendants' reliance on the fair use doctrine by shifting the burden to plaintiffs to establish the existence of a competitive nexus as a condition precedent to sustaining the cause. Additionally, it would solve much of the derivative works problems, where substitutability is widely interpreted.

The foreseeability requirement is also likely to be of significant indirect value from a utilitarian perspective. With copyright liability now made contingent on the existence of a commercial market (and unfair competition therein), a creator has little incentive to create without simultaneously developing a market for the creative work. By disincentivizing private creation devoid of public commercialization,

${ }^{23}$ Professor Gordon rejects using a subjective foreseeability test both within and outside the copyright context. See Gordon, supra note 20, at 238 \& n.337; Wendy J. Gordon, An Inquiry into the Merits of Copyright: The Challenges of Consistency, Consent, and Encouragement Theory, 41 STAN. L. REV. 1343, 1385 (1989) (“[A] rule of law that denied authors compensation except to their 'expected' markets could cause line-drawing problems that would dampen the incentives that new markets should bring.").

${ }^{24}$ See Stadler, supra note 2, at 905-06 (commenting on such an occurrence in response to the Google Library Project).

${ }^{25}$ See id. at 942-58 (detailing the problems of personal copying, of copyright holders making an "end run" around the copyright laws to increase protection, and of the minor role that the fair use doctrine has played in copyright analysis). 
the requirement is more likely to encourage public, commercial distribution. ${ }^{26}$

Central to moving copyright toward a model of unfair competition is the belief that the mere act of copying, devoid of competitive harm, should not be forbidden-a belief that I share with Professor Stadler. ${ }^{27}$ Implicit in this belief is the assumption that when copying is accompanied by commercial harm, either directly (when the work is commercialized without distribution) or indirectly (through distribution), it should be restricted on corrective justice grounds. Eliminating all restrictions on copying ignores this nuance. A restitutionary approach to unfair competition, embedded within the actual doctrines of copyright law, achieves precisely this result, by allowing courts to contextualize competition and to move the doctrine along incrementally.

\section{The Competitive NeXus IN ACTION: BEYOND COPYING}

Adopting a functional, competitive nexus prerequisite to copyright infringement is likely to be beneficial across the entire spectrum of copyright's exclusive rights. Within the context of the reproduction right, on which Professor Stadler focuses, a foreseeability requirement is likely to eliminate lawsuits in which the defendant copies a creative work in a market that the creator could not have foreseen at the time of creation. Thus, if Google were to establish that the market in which it is attempting to operate with the Google Library Project is not one that potential competitors could have reasonably foreseen at the time they created their work, the Project's legality under copyright law should not be questioned. The requirement is, however, likely to prove equally useful in the context of copyright's other rights-most notably the right to create derivatives and the public performance right.

${ }^{26}$ One might want to expand the direct commercialization requirement to allow for situations in which the creator licenses the work to another to commercialize it, as is generally the case with individual authors. Commercialization should not be interpreted as analogous to the market for licensing, as doing so would result in a circularity that courts frequently recognize. See Stadler, supra note 2, at 903-04 \& n.24 (citing, among other sources, 4 MElville B. NimMer \& DAVID NimMER, NimMER ON COPYRIGHT § 13.05[A] [4], at 13-196 to -197 (2006)).

${ }^{27} I d$. at $909,927-28$. 


\section{A. The Derivate Works Right}

Of copyright's other exclusive rights, the right to control the production of derivative works ${ }^{28}$ suffers from several of the problems that the author identifies with the reproduction right. For one, determining whether a work is a derivative, under the loosely-worded terms of the definition, ${ }^{29}$ often plays into the hands of rights-holders. ${ }^{30}$ Additionally, courts routinely apply the same test, whether in the context of a reproduction right claim or a derivative works claim. ${ }^{31}$ It is not surprising, then, that much along the lines of Professor Stadler's proposal for the reproduction right, others have argued for the abolition of the derivative works right. ${ }^{32}$

The nexus requirement would work to limit the operation of the derivative works right. It would restrict the copyright owner's claim to those derivative works that were objectively foreseeable to the creator at the time of creation. This would accord the owner control over standard derivatives (since they would presumably satisfy the objective test) such as abridgements, motion pictures, and translations, but would preclude owners from blocking derivative works that are genuinely novel or that innovatively employ previous work in an independent market.

In Ty, Inc. v. Publications International Ltd., Judge Posner observed that "copying that is complementary to the copyrighted work ... is fair use, but copying that is a substitute for the copyrighted work ... is not fair use." ${ }^{, 3}$ Professor Stadler rightly notes that this distinction is of little utility unless the relevant (or target) market is first identified. ${ }^{34} \mathrm{~A}$

${ }^{28} 17$ U.S.C. $\$ 106(2)(2000)$.

${ }^{29} 17$ U.S.C. $\$ 101(2000)$.

30 See 1 Melville B. Nimmer \& DAVID Nimmer, Nimmer ON COPYRight § 3.01, at 3-3 to -5 (2007) (noting that the definition of a derivative work as being " "based upon one or more pre-existing works" implies that a derivative work "must incorporate that which itself is the subject of copyright").

${ }^{31}$ See, e.g., Well-Made Toy Mfg. Corp. v. Goffa Int'l Corp., 354 F.3d 112, 117 (2d Cir. 2003) (finding no infringement when a secondary work transforms the primary work such that "the two works cease[] to be substantially similar"); Castle Rock Entm't, Inc. v. Carol Publ'g Group, Inc., 150 F.3d 132, 141-43 (2d Cir. 1998) (finding a copyright violation in part because the defendant's work did not appreciably transform the plaintiff's primary work).

${ }^{32}$ See Derek E. Bambauer, Faulty Math: The Economics of Legalizing The Grey Album, 59 ALA. L. REV. (forthcoming 2008), available at http://ssrn.com/ abstract $=979833$ (arguing that abolishing the derivative works right is likely to have significant economic benefits).

${ }_{33} 292$ F.3d 512, 517 (7th Cir. 2002).

${ }^{34}$ Stadler, supra note 2, at 935-36. 
competitive nexus requirement would achieve precisely this, and move the emphasis from fair use to the scope of the exclusive right. The defendant would no longer have to establish that his work is complementary or transformative; rather, the plaintiff would have to show that the defendant's work is situated in a market that she could reasonably have expected to enter when she created the work.

\section{B. The Performance Right}

Two landmark Supreme Court cases, both implicating the public performance right and decided under pre-1976 copyright law in the formative era of the domestic television industry, evince concerns nearly identical to those that the competitive nexus rule helps to alleviate. It is worth considering how these cases might have been on stronger doctrinal footing had the requirement actually been in place. $^{35}$

Both cases involved a rather simple question: whether a cable operator's capturing of copyrighted content from publicly available, over-the-air broadcasts, and its commercial retransmission of the same to its customers, amounted to an infringement. The Supreme Court answered the question in the negative not once, but twice. In Fortnightly Corp. v. United Artists Television, Inc., the Court concluded that since cable companies received content broadcast freely over the air, much like ordinary home viewers, and then relayed it through "private channels," they were not "performing" the work in any sense of the term, but merely facilitating viewers' access to already available content. ${ }^{36}$ In his dissent, Justice Fortas, perhaps rightly, accused the majority of providing the cable industry with a subsidy to "foster [its] development." ${ }^{, 3}$ A few years later, in Teleprompter Corp. v. Columbia Broadcasting System, Inc., the Court reaffirmed its earlier decision. ${ }^{38}$ It emphasized that cable operators were relaying to viewers "signals that could not normally be received" without them. ${ }^{39}$

\footnotetext{
${ }^{35}$ For a detailed analysis of these decisions and their impact on the regulatory regime, see Shyamkrishna Balganesh, The Social Costs of Property Rights in Broadcast (and Cable) Signals, 22 BERKELEY TECH. L.J. 1303 (2007).

${ }^{36} 392$ U.S. 390, 398-401 (1968).

${ }^{37}$ Id. at 404-05 (Fortas, J., dissenting).

38415 U.S. 394, 401-02, 415 (1974) (affirming the Second Circuit's application of the Fortnightly Corp. rule).

${ }^{39} I d$. at 408.
} 
The doctrinal basis of the Court's reasoning in both cases remains unquestionably shaky. ${ }^{40}$ The Court's concern was that the cable operators' profits were not causing the copyright owner/broadcaster any competitive loss, but it lacked a doctrinal hook on which to center its analysis of this connection. A foreseeability requirement would have allowed the Court to reach the same conclusions, but on firmer doctrinal footing. Unless the copyright owners in both cases could affirmatively establish that they could have objectively foreseen operating in the cable television market when the work was created (an uphill task, given that the market did not exist until after most of the works in question were created), their claims would fail. The absence of a foreseeable competitive nexus between the cable operators and the copyright owners/broadcasters would leave the operators' actions outside of the scope of infringement liability.

\section{CONCLUSION}

As should be apparent, I agree with much of Professor Stadler's basic intuition that the norms of unfair competition ought to make their way into copyright law and refine the way in which courts and lawmakers think about the subject. Where I part company with her, though, is merely in identifying the best way of implementing this ideal. Professor Stadler makes an exceptionally strong case for the copyright/unfair competition interface and in the process unearths much of the irrationality that has kept the two disciplines apart. For this reason alone, it should be valuable reading for anyone interested in the issue of copyright reform.

To many, Professor Stadler's proposal (and perhaps my alternative) will appear inexplicably radical, given the rhetoric of piracy and the expansionary momentum that permeate copyright debates. All the same, if it even so much as causes judges and lawmakers to take notice of the similarities between copyright and unfair competition and of the beneficial synergies they are capable of producing, it will have gone a long way in making an enduring contribution to the subject.

${ }^{40}$ See, e.g., Gillis L. Heller, Comment, Regulatory Versus Property Rights Solutions for the Cable Television Problem, 69 CAL. L. REV. 527, 534-35 (1981) (arguing that advances in copyright law had not kept pace with the technological advances of cable television). 
Preferred Citation: Shyamkrishna Balganesh, Response, Rethinking Copyright: Property Through the Lenses of Unjust Enrichment and Unfair Competition, 156 U. PA. L. REV. PENNUMBRA 345 (2008),

http:/ /www.pennumbra.com/responses/01-2008/Balganesh.pdf. 